\title{
The energy saving effect of incorporating an ATRIUM into a building
}

\author{
R. Getino-De la Mano - Dr. J. L. Falagán Cavero - E. Getino Grande \\ Dpto. de Ing. Eléctrica y de Sistemas y Automática \\ UNIVERSIDAD DE LEÓN \\ Campus of Vegazana - León (Spain)
}

Phone/Fax number:+0034 987 291000, e-mail: rgetm@unileon.es, jlfalc@unileon.es, egetig00@estudiantes.unileon.es

\begin{abstract}
.
The member states of the European Union have set a 2020 target to reduce energy consumption by $20 \%$ relative to figures for 1990. In 2011, the total energy consumption of the building and installation sector in Spain was 299,558 gigawatt hours, accounting for $29.9 \%$ of the total national consumption for other uses of 1,000,720 gigawatt hours [1].

Directive 2010/31/EU of the European Parliament and of the Council of May 19th, 2010, on the energy performance of buildings, establishes the objective of promoting energy efficiency in buildings located in the EU, through the consideration of factors such as outdoor climatic and local conditions as well as indoor climate requirements and costeffectiveness in heating costs.
\end{abstract}

This article, based on data collected during a 12 month study of a real building, shows that an energy saving heating and cooling of $19.62 \%$ can be achieved through the incorporation into buildings of atrium-style open spaces with energy functions.

\section{Key words}

Air accumulator, energy saving, atrium, bioclimatic architecture, passive solar gain, almost zero consumption buildings, energy efficiency, buffer space, reducing $\mathrm{CO}_{2}$, building sector, air circulation in buildings.

\section{Introduction}

The energy consumption of buildings is very high: in 2011, the total energy consumption of the building and installations sector in Spain amounted to 299,558 gigawatt hours. This level of consumption renders the country highly dependent on foreign monopoly markets for its energy supply, and entails a high rate of emissions, especially of $\mathrm{CO}_{2}$. It has been estimated that the consumption of 299,558 gigawatt hours generates around 69,624 million kilograms of $\mathrm{CO}_{2}$ emissions per year.

An approach to the construction of buildings that incorporated bioclimatic concepts and an energy efficiency perspective would contribute to a reduction in the energy consumption of buildings and in emissions of air pollutants.
According to the Oxford English Dictionary, "atrium" is a Latin word meaning the open space in the centre of an ancient Roman villa. However, if instead of being open the atrium were integrated into the interior of a building, it would constitute a free space where air can accumulate. Then, if this free space were to be equipped with glass windows on its southern and eastern sides, it would become a passive solar energy collector. Furthermore, if the atrium were connected via air ducts with a HVAC (Heating, Ventilation and Air Conditioning) system, it would in fact, represent a free hot air producer that could be used for climate control in the occupied areas of the building thus constructed.

The use of passive solar gain in buildings is a concept drawn from bioclimatic architecture which undeniably contributes very favorably to achieving the goals established in the Directives of the European Parliament and the Council concerning the energy efficiency of buildings.

One of the priority objectives established by the Directives on energy efficiency published to date is the promotion of energy efficiency of buildings located in the EU, through the consideration of factors such as outdoor climatic and local conditions as well as indoor climate requirements and cost-effectiveness, introducing a fundamental concept, the "almost zero energy consumption of buildings".

In these directives, an "almost zero energy consumption building" is defined as a building with a very high level of energy efficiency. The almost zero or very low amount of energy required should be met to a very large extent by energy from renewable sources, including energy from renewable sources produced in situ or in the surrounding environment [2].

Among other factors involved in the energy consumption of buildings, Annex I of Directive establishes the need to consider the use of optimal and efficient passive heating and cooling systems. 
Bioclimatic architecture can be defined as the "art of designing and constructing buildings for living taking climatic conditions into account".

There are several criteria to consider when constructing a building using an approach based on bioclimatic architecture: (i) such as positioning, (ii) location, (iii) external elements, (iv) the building's shape, (v) orientation, (vi) passive solar energy, (vii) the greenhouse effect, (viii) protection against solar radiation in summer, (ix) thermal mass, (x) insulation systems, (xi) circulation systems, (xii) ground heat exchange, (xiii) buffer spaces, (xiv) evaporative cooling systems, (xv) aquatic plant systems for regulating temperature and moisture, etc.

Several bioclimatic effects can be achieved with the design of an atrium; for example, provided that it is in direct contact with the outside, one of these is passive solar gain, whereby the air inside is heated, at no cost, and can later be used to heat the occupied areas. Another bioclimatic effect can be achieved through the atrium's function as a buffer space or an energy accumulator space, since the air accumulated inside an atrium presents more favourable temperature and humidity levels than the air outside or in other areas of the building.

When an atrium is functioning correctly from an energy point of view, up to $19.62 \%$ less energy is required to heat/cool the air used for climate control.

\section{Study of a real atrium}

The atrium under study was constructed specifically to perform an energy saving function. It was located inside a building measuring $1852.00 \mathrm{~m}^{2}$ which consisted of 6 floors, one below and 5 above ground level, with a heating demand of $106.00 \mathrm{~kW}-\mathrm{h} / \mathrm{m}^{2}$ and a cooling demand of 52.0 $\mathrm{kW}-\mathrm{h} / \mathrm{m}^{2}$. The measurements taken during this study demonstrate the energy savings achieved.

The building presented several special characteristics in terms of its architecture and installations, since it incorporated many concepts related to bioclimatic architecture, such as a consideration of local conditions and an orientation aimed at exploiting the thermal effects of solar energy gain.

The heating and cooling systems were designed and installed with a view to obtaining greater energy efficiency. Features included very efficient heat and cold production, active use of solar energy, a micro combined heat and power system, an absorption system and distribution of hot water for heating based on the areas to be heated, whereby depending on the efficiency of the system in question for each case, use was made of the effect of convection or radiation, cold ceiling and accumulation of free energy in the form of hot air or hot water.

The building also included an open space, the atrium, which measured 15 meters high with a floor area of 120 square meters, giving a total rectangular volume of 1,800 cubic meters.
This space contained natural vegetation, which provides oxygen and a source of water which humidified the air.

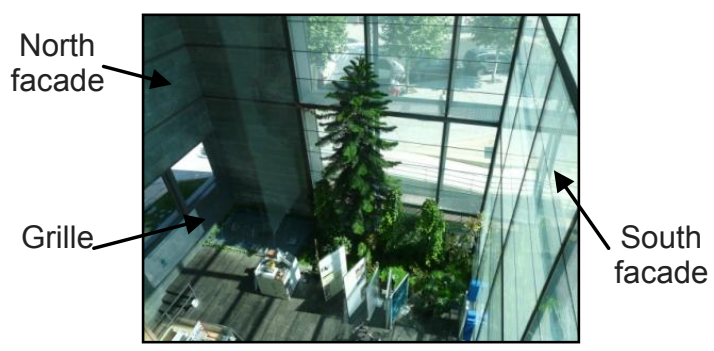

Figure 1: Atrium

Cooling was achieved through an air intake grille measuring 1.40 square metres, which was directly connected to the exterior and faced north (see figure 1).

According to Tian Peizhe and Zhang Enxiang, the cross sectional shape of an atrium influences the thermal characteristics of the space. It is therefore necessary to design the cross section (rectangular or trapezoidal) based on the specific needs of the building. It has been reported that a rectangular atrium presents a lower temperature in summer and maintains higher temperatures in winter [3], and this claim was confirmed by our results; measurements taken inside the atrium under study showed that winter temperatures remained higher inside than outside while air temperatures inside the atrium in summer were lower than outside.

On the other hand, the differences between external environmental temperatures and the temperatures inside a trapezoidal or inverted trapezoidal atrium are less than optimal compared with a rectangular atrium, with relatively high temperatures in the summer, and relatively low temperatures in winter. Cooling is also better in a rectangular atrium than in a trapezoidal atrium.

In general, a rectangular atrium provides a much better thermal environment than atriums with other types of cross section, and is thus the most suitable design for buildings located in regions with hot summers and cold winters [3], as is the case of Leon (Spain), the city in which the building under study is located.

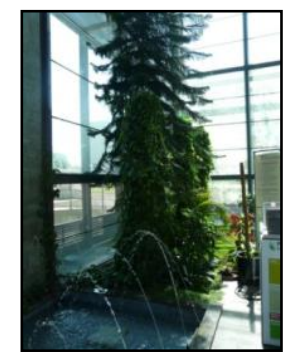

Figure 2: Atrium. Fountain and vegetation

\section{1- Design of the Atrium}

The north-facing wall of the atrium, which presented a total surface area of $136 \mathrm{~m}^{2}$ and consisted of six layers of materials of different thicknesses and thermal characteristics, functioned as an energy accumulator. 


\begin{tabular}{|l|c|c|c|}
\hline Type of material & $\begin{array}{c}\text { Thickne } \\
\text { ss }(\mathbf{c m})\end{array}$ & $\begin{array}{c}\text { Thermal } \\
\text { Conductivity } \\
(\boldsymbol{\lambda})(\mathbf{W} / \mathbf{m K})\end{array}$ & $\begin{array}{c}\text { Resistance } \\
(\mathbf{m} 2 \mathbf{K} / \mathbf{W})\end{array}$ \\
\hline Outer surface layer & - & - & 0.04 \\
\hline Slate & 4.00 & 2.2 & \\
\hline Air chamber & 7.00 & - & 0.90 \\
\hline Cement Mortar & 2.00 & 1.30 & \\
\hline Ceramic block & 29.00 & 0.421 & \\
\hline Cement Mortar & 2.00 & 1.30 & \\
\hline Slate & 3.00 & 2.2 & \\
\hline Outer surface layer & - & - & 0.13 \\
\hline
\end{tabular}

Table 1.- Composition of north wall

With this design, the wall as a whole presented a thermal transmittance of $\mathbf{U}=\mathbf{0 . 5 5} \mathbf{W} / \mathbf{m}^{2} \mathbf{K}$. [4].

When heated by direct solar radiation, this structural element stored energy as heat. Through the effect of conduction, the temperature of the outer surface of the wall was then transmitted through the various layers to the inner surface of the wall, which in turn heated the air in contact with the wall by convection or radiation. Due to the height of the north wall and the different temperatures it attained throughout the day and over the seasons as a result of the Sun's position, the air inside was stratified by temperature, with the hot air moving up towards the upper section of the atrium.

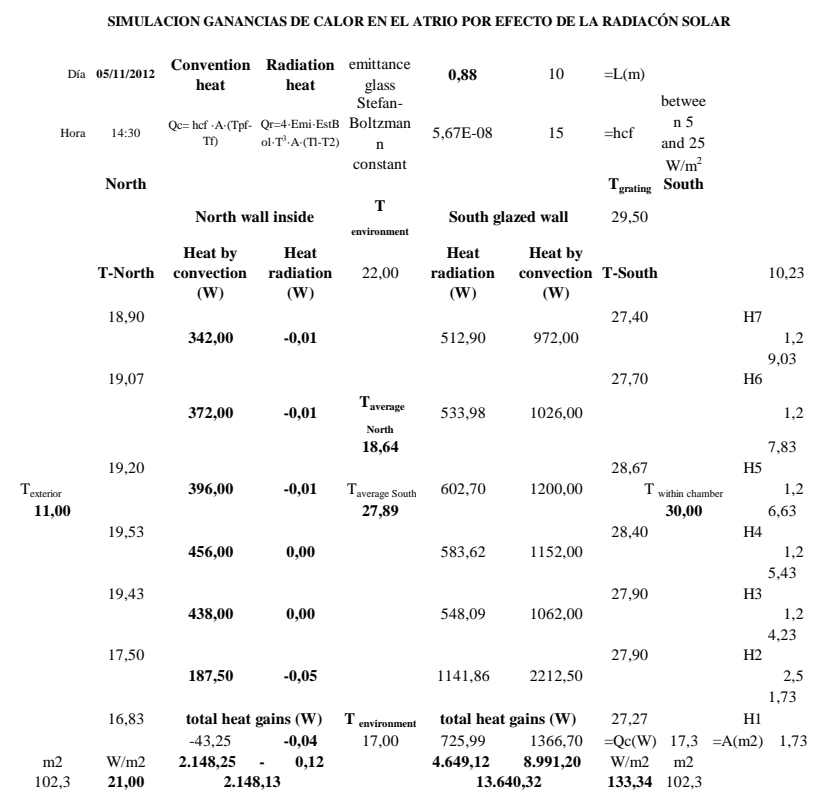

Figure 3: Simulation of the energy gains the effect of solar radiation

The vertical temperature distribution in an atrium, has been proven by mathematical modeling [5]

In a space of large dimensions, air stratification by temperature is an obvious result which is strongly influenced by solar radiation, and also by the materials used [6].

Due to the effects of solar radiation, the temperature of the north wall varied over the course of the day and also throughout the year. On the basis of the measurements taken on the inner surface of the north wall $(7 \times 3$ grid pattern) on November 5th at 14:30, the average surface temperature of the inner wall was $18.64^{\circ} \mathrm{C}$ and the average outer wall surface temperature was $11^{\circ} \mathrm{C}$. In accordance with these data, the temperatures in each layer are given in figure 4.

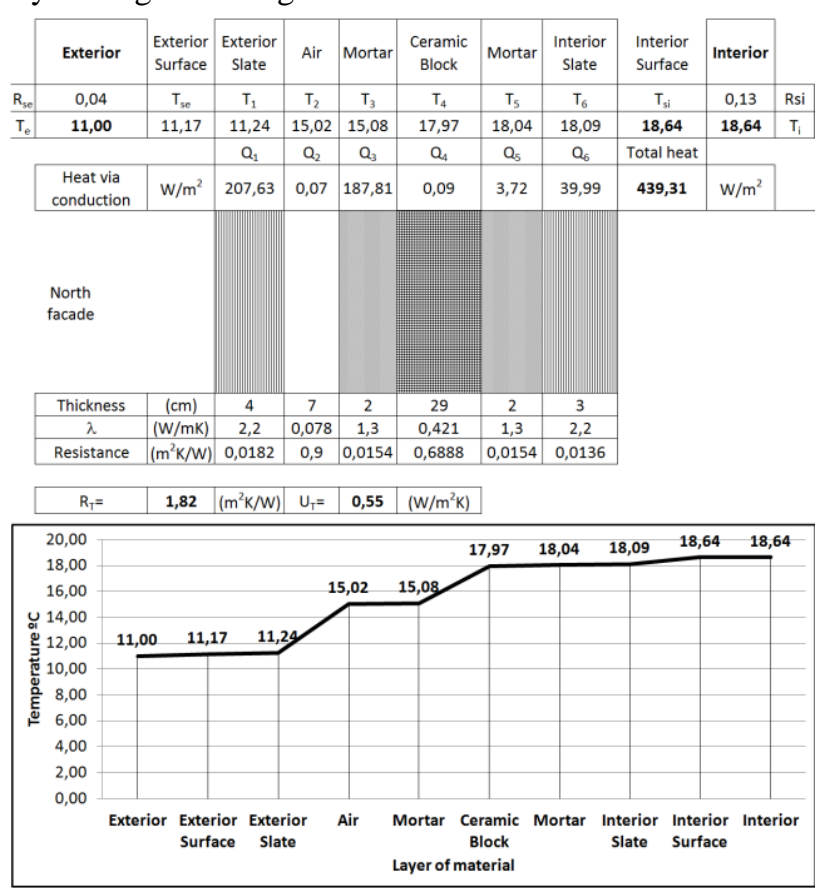

Figure 4.- Temperatures of each layer in the north wall in November

Meanwhile, on a summer day, the inner wall surface temperature was $40^{\circ} \mathrm{C}$ and the outer surface temperature was $27^{\circ} \mathrm{C}$; thus, the temperatures of each layer were as indicated in Figure 5.

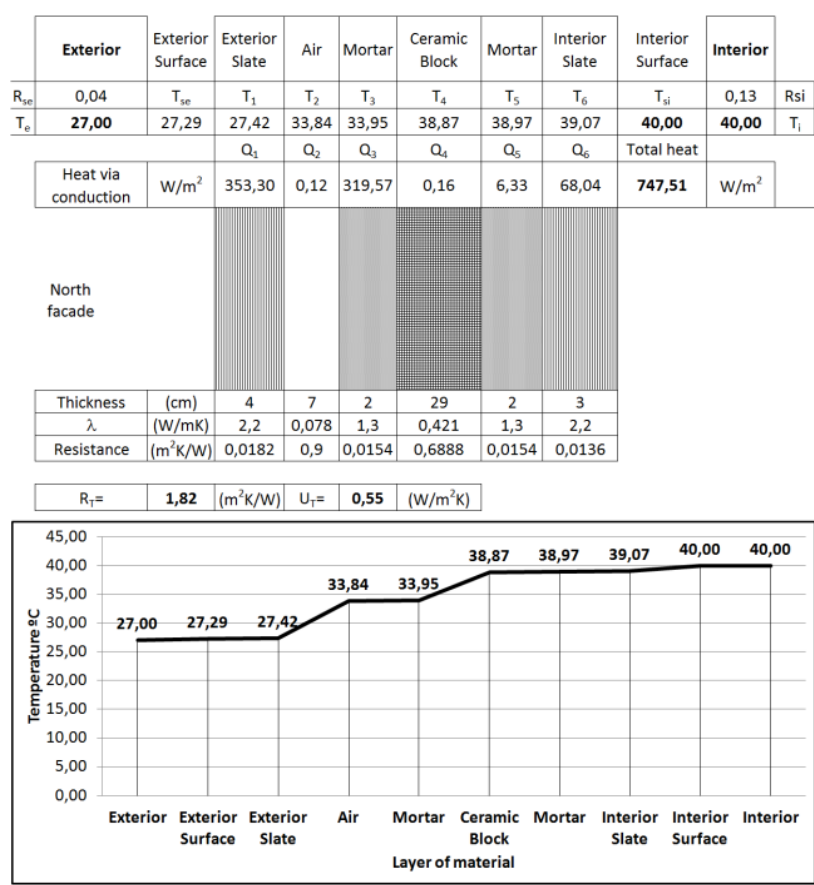

Figure 5.- Temperatures of each layer in the north wall in July

The south and east faces were completely glazed with a "double skin" consisting of two separate glass walls set 1.2 metres apart (see figure 6), thus forming a chamber 
between the two walls. A grille set in the lower outer wall and located at $1 \mathrm{~m}$ above ground height enabled air from the outside to be introduced naturally into this chamber and to circulate inside it. The south face had a surface area of $136 \mathrm{~m}^{2}$ and functioned as a vast passive solar energy collector; through radiation and convection, this energy was then transmitted in the form of heat to the air in direct contact with the wall inside the atrium.

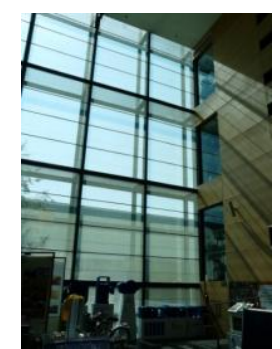

Figure 6. Glazed south face

\section{2. - Monitoring}

To obtain the data, 5 temperature probes were installed which simultaneously measured and continuously recorded values for the following parameters: (i) external temperature on the north wall, (ii) temperature inside the atrium at 1.5 metres above floor height, (iii) temperature inside the atrium at 14.5 metres above floor height (temperature of the air used by the HVAC system), (iv) temperature inside the south-facing chamber at 15 metres above floor height y (v) supply air temperature, calculated by the existing control system according to the external temperature, the level of heating required to satisfy heating demand in the occupied areas of the building and the preprogrammed setpoint temperature.

22,464 items of data were recorded, of which 18,720 corresponded to working days and were used in this study, whilst the remaining 3,744 items of data were excluded as they corresponded to non-working days.

\section{Atrium behaviour and results}

The air in the atrium was used to cool and heat the occupied areas of the building. Thus, when the preprogrammed climate control system detected that the air temperature and humidity conditions were suitable, it extracted air from the atrium via a grille which was located in the upper section of the atrium and fed into a direct conduit.

Containing $1,800 \mathrm{~m}^{3}$ of air, the atrium supplied $30 \%$ of the building's climate control requirements, since $6,000 \mathrm{~m}^{3}$ of air would have been required to heat/cool all of the occupied areas.

This approach ensures an annual energy saving in heating of $18.07 \%$. The energy savings in cooling would be $1.55 \%$, in total $19.62 \%$, representing a total energy saving of $104,573.71 \mathrm{~kW}-\mathrm{h}$ per year, equivalent to $\mathbf{5 6 . 4 7} \mathbf{~ k W}$ $\mathbf{h} / \mathbf{m}^{2}$ (heat $=55.66 \mathrm{~kW}-\mathrm{h} / \mathrm{m}^{2}$ and cold $\left.=0.81 \mathrm{~kW}-\mathrm{h} / \mathrm{m}^{2}\right)($ see figure 7).

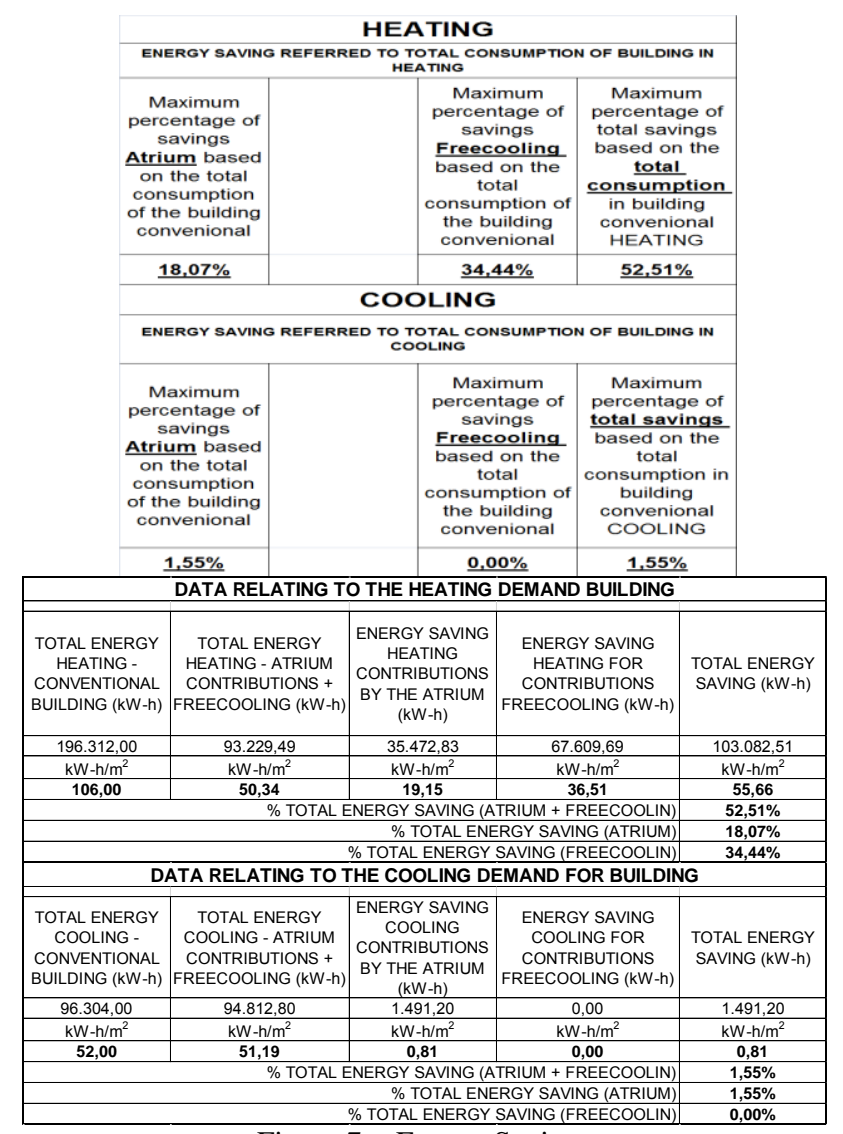

Figure 7.- Energy Savings

In winter, the air inside the atrium was maintained at much higher, more comfortable temperatures than the air outside. Furthermore, for a very high percentage of the time in summer, the air inside the atrium remained cooler than temperatures outside. The measurements taken revealed that the atrium generated energy savings.

It has been found that, energy savings were higher in the winter than in the summer, due to the location of the project in an area of the country as cold as Leon, classified according to the Technical Building Code as an E1 region.

It should be noted that the minimum temperature value recorded inside the atrium was $9.30^{\circ} \mathrm{C}$, whereas the minimum temperature value recorded outside the building was $-5.80^{\circ} \mathrm{C}$, representing a temperature difference of $15.1^{\circ} \mathrm{C}$. Meanwhile, the average minimum value inside the atrium was $11.40^{\circ} \mathrm{C}$, but outside the building this was $-0.87^{\circ} \mathrm{C}$, representing an average temperature difference of $12.27^{\circ} \mathrm{C}$.

The highest temperature recorded in the atrium over the entire period of study was $24.90^{\circ} \mathrm{C}$, whereas outside this was $25.80^{\circ} \mathrm{C}$ in the shade and $40^{\circ} \mathrm{C}$ in the sun, which would be the average reference temperature in a building of conventional construction which made no use of an atrium or of the shadow cast by the building itself on the air intake grille.

These results clearly identify the energy savings generated, because instead of heating/cooling air taken directly from outside, for example in winter with 
temperatures as low as $-5.80^{\circ} \mathrm{C}$ or in summer with temperatures as high as $40^{\circ} \mathrm{C}$, the building was heated in winter with air which never fell below $9.30^{\circ} \mathrm{C}$ and cooled in summer with air which never rose above $24.90^{\circ} \mathrm{C}$.

Figure 8 depicts a situation in which the control system extracts air for the HVAC system from the upper section of the atrium, at a temperature of $15.3^{\circ} \mathrm{C}$, while the outdoor temperature is $8.6^{\circ} \mathrm{C}$. In other words, there is a temperature difference of $6.7^{\circ} \mathrm{C}$ which will not need to be compensated for by consuming fuel in the boiler, since the atrium functions as an accumulator of air which is at a higher temperature than the air outside, thanks to the passive uptake of solar radiation in the preceding hours.

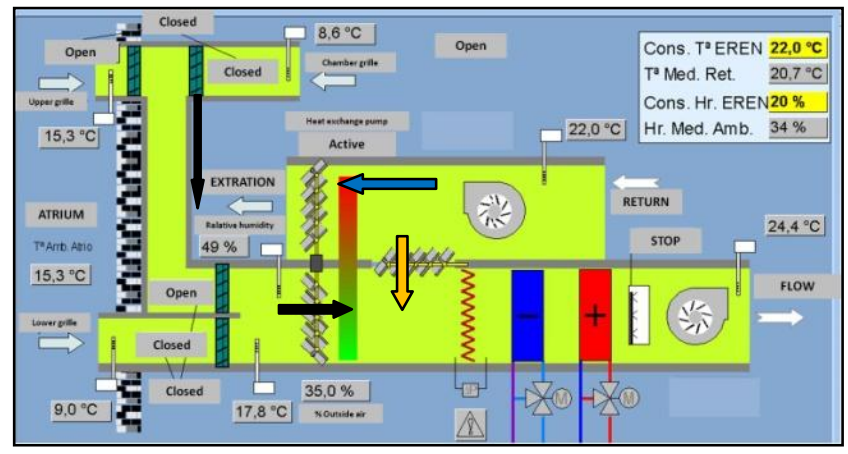

Figure 8.- HVAC System Operation

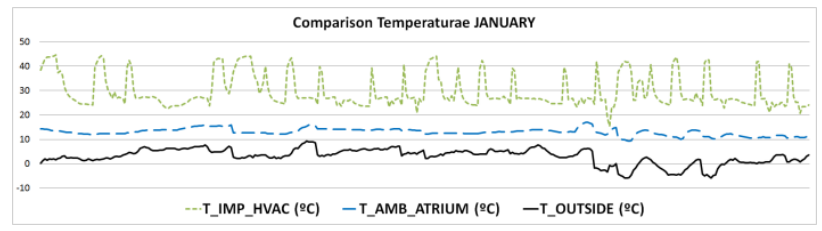

Figure 9.- Temperatures January. Outside temperature - Atrium temperature - HVAC temperature

As can be seen, heat is only required to raise the temperature from $17.8^{\circ} \mathrm{C}$ to $24.4^{\circ} \mathrm{C}$, since in this case, a further $2.5^{\circ} \mathrm{C}\left(17.8^{\circ} \mathrm{C}-15.3^{\circ} \mathrm{C}\right)$ is being exploited thanks to the installation of a heat pump and the "free cooling" effect.

In the figure 9, comparisons are shown below between: (i)the temperature of the air in the atrium (T_AMB_ATRIUM) (short dashed line), (ii)the temperature of the air outside (T_OUTSIDE) (continuous line) y (iii)the air temperature which the automated control system calculated was necessary before directing air for cooling/heating into the occupied areas. (T_IMP_HVAC) (long dashed line)

It can immediately be seen that when it was necessary to heat the occupied areas, the temperature difference to compensate was much lower when the air is taken from the atrium (blue line) than when it was taken from the outside (red line), while when it was necessary to cool these areas, the temperature difference between the required temperature and the temperature of the air in the atrium was lower than between the required temperature and air taken directly from outside. Furthermore, it should also be borne in mind that in the case under study, air intake from the outside was strategically located to exploit the shadow cast by the building itself instead of being situated, as is the normal practice, on the building's roof, thus already implying significant savings by avoiding the intake of outside air at extremely high temperatures.

The data obtained from the measurements confirm that substantial energy savings are obtained from an atrium. As a result of these temperature differences in the air, energy savings can be quantified based on the volume of air used and the energy savings obtained in winter through not having to heat the HVAC air from temperatures below zero up to the minimum registered temperature in the atrium, or in summer, through not having to cool the air from the maximum of $40^{\circ} \mathrm{C}$ recorded as the outside air temperature.

The graph below depict energy savings per 1 cubic metre of air for each week. The area between the blue line (upper HVAC air intake vent in the atrium) and the black line (air intake from outside) represents the amount of energy saved. $17.42 \mathrm{~kW}$-h/year by cubic meter of air cooled/heated.

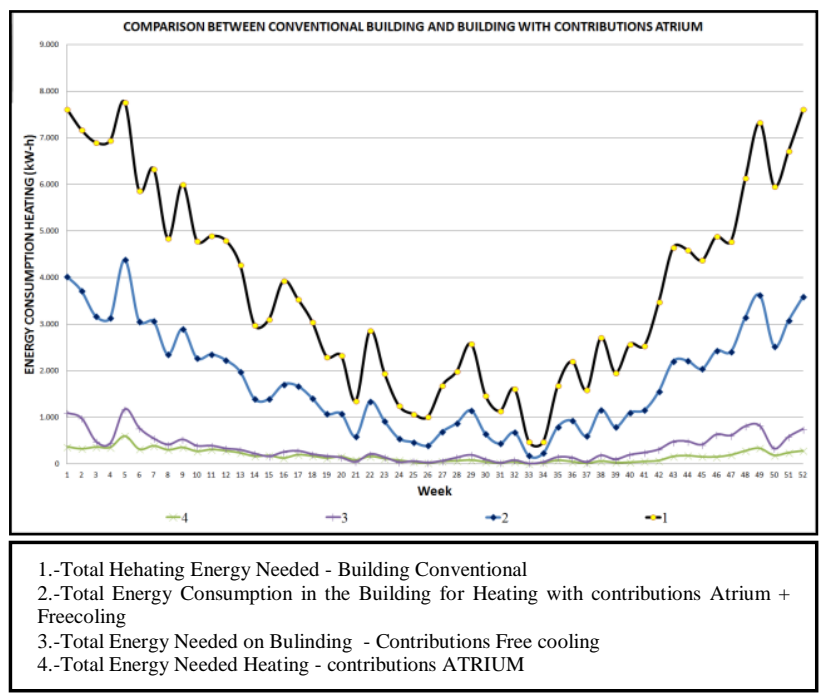

Figure 10.- Energy savings in heating

\section{Mathematical expression}

The energy savings generated by the existence of an atrium can be expressed mathematically as a function of the following parameters:(a)volume of air in the atrium, i.e. surface and height of free space (VA) $\left(\mathrm{m}^{3} / \mathrm{h}\right)$, (b)specific air heat $(\mathrm{SAH})(\mathrm{J} / \mathrm{kgK})$, (c)density of air depending on the temperature (DA) $\left(\mathrm{kg} / \mathrm{m}^{3}\right)$, (d)flow temperature of the building's HVAC system (FT) (K) y (e)temperature of air taken from the atrium for circulation (TAA) (K).

On the basis of the parameters given above, the energy that would be required when taking the air from the atrium is expressed below (ERA):

$$
E R A(k W-h)=\frac{V A \cdot S A H_{a t r i o} \cdot D A_{a t r i o} \cdot(F T-T A A)}{3,6 \cdot 10^{5}}
$$

Note: $3,6 \cdot 10^{5}$, units conversion factor

In turn, the energy that would be required when taking the air from outside is expressed as follows (ERO): 
$E R O(k W-h)=\frac{V A \cdot S A H_{\text {exterior }} \cdot D A_{\text {exterior }} \cdot(F T-T A A)}{3,6 \cdot 10^{5}}$

The energy saving is the difference between ERO and ERA

$$
A E(k W-h)=E R O-E R A
$$

\section{Discussion}

As indicated in the study by Abdelsalam Aldawoud and Ray Clark entitled " Comparative analysis of energy performance between courtyard and atrium in buildings"[7], as the height of a building increases, the energy efficiency of the atrium improves. The point of equilibrium will depend on several factors, including glazing parameters and the climate of the area where the building is located.

The measurements taken in the real atrium which served as a model confirm the validity of this assertion as regards winter, since the energy performance of the atrium was much better in its upper section, where more optimal conditions were produced.

However, in their paper entitled "Analytical model of atrium for heating and ventilating an institutional building naturally"[8], indicated that the incorporation of an atrium into a building will not automatically lead to energy savings, and also claimed that the energy consumption of a building may be higher than that of a building of similar geometry but without an atrium. According to these authors, more energy is required due to the greater need for artificial lighting and mechanical circulation.

Their research shows the relationship between passive heating, the effect of cooling and the construction of an atrium in a building. However, their study was carried out on a fictitious three-floor building located in Tehran.

The results obtained in the present study of a real atrium in an occupied building did not confirm their conclusions, since the measurements taken in the real atrium indicated that a considerable reduction in energy consumption was obtained, due to the differences in temperature between the air outside and inside the atrium, at least in Leon (Spain), the city in which the building studied was located.

\section{Conclusions}

It is mandatory in Europe to achieve the energy consumption objectives set for the year 2020, namely a $20 \%$ reduction in energy consumption relative to figures for 1990. Furthermore, the measures undertaken by member states are expected to be cost-effective measures based on maximum efficiency ratios.

Therefore, those involved in the building sector, i.e. property developers, building owners, architects, builders and the public authorities, should assume the obligations entailed for all member states and apply the knowledge, tested alternatives and cost-effective options proposed for the construction and/or renovation of buildings in order to meet the target of reducing energy consumption by $20 \%$ in 2020 .

As has been demonstrated in this paper, the incorporation of an atrium type space or similar represents a real contribution of no less than $19.62 \%$ to the reduction of energy consumption in buildings, according to the annual energy savings calculated for the building that served as a real example in this study. Characterised architecturally as being a bioclimatic and energy efficient building, the initial associated costs of such a building are relatively low and manageable, especially given the lower costs implied by the calculated savings in energy and the consequent reduced dependence on foreign markets for fuel supplies and reduced emissions of $\mathrm{CO}_{2}$ to the atmosphere.

Buildings with a correctly proportioned and strategically located atrium type space would save $17.42 \mathrm{~kW}-\mathrm{h}$ annually per cubic metre of air cooled/heated, representing a reduction in emissions of $\mathrm{CO}_{2}$ into the atmosphere of $4.38 \mathrm{~kg}$ per year and per cubic metre of air cooled/heated compared with using natural gas as fuel $\left(0.252 \mathrm{kgCO}_{2} / \mathrm{kW}-\mathrm{h}\right)[9]$.

It is difficult to find official data on the floor area of buildings. However, in Spain it has been estimated that the volume of air heated each year is on the order of 6,900 million cubic metres, when considering both residential and tertiary sector buildings together. Therefore, applying the atrium approach would imply energy savings of around 120,198 gigawatt hours a year, equivalent an approximately $\underline{\mathbf{3 0 . 2 2 2} \text { million } \mathbf{~ k g}}$ $\underline{\text { reduction in } \mathrm{CO}_{2}} \underline{\text { emissions }}_{\text {, a }}$ approximately $\underline{720 \mathrm{~kg} \text { per }}$ per inhabitant and year

\section{References}

[1] IDAE. Informe Anual de consumos energéticos Año 2011.

[2] Parlamento Europeo y Consejo Europeo, Directiva 2010/31//UE, relativa a la eficiencia energética de los edificios.

[3] Tian Peizhe, Zhang Enxiang, Guo Guangling, Study on the Thermal Environment in Building Atrium with Different Sections under the Condition of Natural Ventilation, 2010.

[4] Código Técnico de la Edificación, Apéndice E cálculo de los parámetros característicos de la demanda. Documento básico HE ahorro de energía, 2006.

[5] Xin Wanga, Chen Huang, Weiwu Cao. Mathematical modeling and experimental study on vertical temperature distribution of hybrid ventilation in an atrium building. Energy and Buildings 41 (2009) 907-914.

[6] Chuancheng Li, Junyi Zhang, Zhaozhao Zhang, Qunfeng Ji, The temperature stratification measurement and simulation in atrium Of Wuhan Station, Wuhan, China: IEEE, 2011.

[7] Abdelsalam Aldawoud, Ray Clarkpublished. Energy and Buildings, Volume 40, Issue 3, 2008, Pages 209-214.

[8] M. Khalaji Assadi, F. Dalir and A.A. Hamidi. Analytical model of atrium for heating and ventilating an institutional building naturallyand. Energy and Buildings, Volume 43, Issue 10, October 2011, Pages 2595-2601.

[9] Ministerio de Industria, Energía y Turismo. Gobierno de España. Factores de emisión de $\mathrm{CO}_{2}$. Documento Reconocido.2014. 